\title{
The Antiapoptosis Effect of Glycyrrhizate on HepG2 Cells Induced by Hydrogen Peroxide
}

\author{
Miao Su, Tengfei Yu, Hong Zhang, Yan Wu, Xiaoqin Wang, and Gang Li \\ Department of Pharmacology, Pharmacy School, Inner Mongolian Medical University, Jinshan Developing Zone, \\ Hohhot, Inner Mongolia 010110, China \\ Correspondence should be addressed to Gang Li; cnnmligang@hotmail.com
}

Received 17 April 2016; Revised 25 August 2016; Accepted 28 September 2016

Academic Editor: Javier Egea

Copyright (C) 2016 Miao Su et al. This is an open access article distributed under the Creative Commons Attribution License, which permits unrestricted use, distribution, and reproduction in any medium, provided the original work is properly cited.

This study demonstrated that glycyrrhizate (GAS) could protect HEPG2 cells against damage and apoptosis induced by $\mathrm{H}_{2} \mathrm{O}_{2}$ $(1600 \mu \mathrm{M}, 4 \mathrm{~h})$. Cell viability assay revealed that GAS was noncytotoxity at concentration $125 \mu \mathrm{g} / \mathrm{mL}$, and GAS $(5 \mu \mathrm{g} / \mathrm{mL}, 25 \mu \mathrm{g} / \mathrm{mL}$, and $125 \mu \mathrm{g} / \mathrm{mL}$ ) protected HepG2 cells against $\mathrm{H}_{2} \mathrm{O}_{2}$-induced cytotoxicity. $\mathrm{H}_{2} \mathrm{O}_{2}$ induced the HepG2 cells apoptosis, obvious morphologic changes were observed after Hochest 33258 staining, and more apoptotic cells were counted in flow cytometry assay compared to that of the natural group. Pretreatment GAS $(5 \mu \mathrm{g} / \mathrm{mL}, 25 \mu \mathrm{g} / \mathrm{mL}$, and $125 \mu \mathrm{g} / \mathrm{mL})$ prior to $\mathrm{H}_{2} \mathrm{O}_{2}$ reverses the morphologic changes and reduced the apoptotic cells in HepG2 cells. GAS reduced the release of MDA, increased the activities of superoxide dismutase, and diminished the release of ALT and AST during oxidative stress in HepG2 cells. After Elisa kit detecting, GAS inhibited the caspase activity induced by $\mathrm{H}_{2} \mathrm{O}_{2}$, GAS decreased the level of caspase- 3 and caspase- 9 from mitochondria in dose-dependent manner. Western blot results showed that pretreatment GAS upregulated the expression of Bcl-2 and decreased the expression of Bax. These results reveal that GAS has the cytoprotection in HepG2 cells during ROS exposure by inhibiting the caspase activity in the mitochondria and influencing apoptogenic factors of the expression of Bax and Bcl-2.

\section{Introduction}

Oxidative stress is a crucial factor that contributes to aging and multiple degenerative diseases, because it can alter biological molecules such as DNA, proteins, and lipids [1]. Chronic oxidative stress may also promote the onset or progression of chronic liver diseases including nonalcoholic fatty liver disease (NAFLD), cirrhosis, hepatitis, and hepatic carcinoma, which if not treated properly are likely to advance to end-stage liver diseases requiring surgical intervention [2]. Major sources of cellular ROS include the mitochondrial respiratory chain and enzymatic reactions mediated by enzyme systems such as xanthine oxidoreductase, nitric oxide (NO) synthase (NOS), and nicotinamide adenine dinucleotide phosphate (NADPH) oxidases [3]. The physiological and pathological relevance of these sources is different depending on the specific disease and tissue/organ. Superoxide $\left(\mathrm{O}_{2}{ }^{-}\right)$and hydrogen peroxide $\left(\mathrm{H}_{2} \mathrm{O}_{2}\right)$, primary ROS products, are indeed involved in a broad range disease progress. Previous studies indicated that extracellular $\mathrm{H}_{2} \mathrm{O}_{2}$ increased intracellular ROS levels via multiple mechanisms including loss of intracellular ROS antioxidants such as glutathione (GSH) [4] or decreased mitochondrial membrane permeability followed by mitochondrial ROS release [5]. Many researches have confirmed that the mechanisms underlying various types of hepatic injuries are induced by robust generation of intracellular reactive oxygen species (ROS) $[6,7]$. Extracellular $\mathrm{H}_{2} \mathrm{O}_{2}$ has been used to induce oxidative injury in hepatocytes at different concentration $[8,9]$. Therefore, $\mathrm{H}_{2} \mathrm{O}_{2}$ was used to induce oxidative injury in HepG2 cells in our study.

Licorice (Glycyrrhiza glabra Linn; family: Leguminosae) has been widely used for several centuries in China, especially in Chinese herbal compound. The Licorice has been reported for antipyretic, antimicrobial, hepatoprotective, antioxidant, anxiolytic, expectorant, laxative, and diuretic properties [1013]. Glycyrrhizate (GAS) was one of the main active ingredients of Licorice. Pharmacology studies in recent years show that GAS has multiple pharmacological effects, including 
adrenal cortical hormone-like effect, anti-inflammatory antihypertensive effect [14], antiaging and enhancing immune function, the enhancement of body's physiological function, and the inhibitory cancer cell growth. But, few researches on GAS can provide enough data particularly with regard to their mechanism to protect cells against oxidative damage. Here we investigated the effects of GAS on oxidative HepG2 cells damage induced by $\mathrm{H}_{2} \mathrm{O}_{2}$ and elucidated the potential mechanism involved in the cytoprotective effect of GAS.

\section{Materials and Methods}

2.1. Chemicals. GAS was obtained from China Institute for Food and Drug control (Beijing, China); the purity of GAS is 98\%. Caspase-3 and caspase-9 Elisa kits were purchased from Wuhan Xinqidi Biological Technology Co., Ltd. (Wuhan, china). Hoechst 33258 stains were purchased from SigmaAldrich, USA. ALT, AST, MDA, and SOD kits were obtained from the Nan Jing Jian Cheng Bioengineering Institute (Nanjing, China). The tubulin antibody was purchased from Beyotime (Shanghai, china). Annexin V-FITC/propidium iodide (PI) apoptosis detection kit was purchased from BD company (American). Anti-Bax antibody and anti-Bcl-2 antibody were purchased from Abcam company (UK). HepG2 cells were purchased from Beijing Concord Cell Resource Center (Beijing, China).

2.2. Cell Culture. HepG2 cells were cultured in a humidified atmosphere of $95 \%$ air plus $5 \% \mathrm{CO}_{2}$ in a $37^{\circ} \mathrm{C}$ incubator in DMEM supplemented with $10 \% \mathrm{FBS}, 100 \mu \mathrm{M}$ streptomycin, and $100 \mathrm{U} / \mathrm{mL}$ penicillin.

2.3. Determination of Cytotoxicity by MTT Assay. Cell toxicity was induced by exposure to $\mathrm{H}_{2} \mathrm{O}_{2}$; cells were challenged with $\mathrm{H}_{2} \mathrm{O}_{2}(1600 \mu \mathrm{M})$ for 4 hours. The MTT assay is based on the principle that viable cells convert MTT into an formazan crystals, whose absorbance at $490 \mathrm{~nm}$ was read in a microplate reader. It has been divided into 5 groups, natural group, $\mathrm{H}_{2} \mathrm{O}_{2}$ group, and GAS $(5 \mu \mathrm{g} / \mathrm{mL}, 25 \mu \mathrm{g} / \mathrm{mL}$, and $125 \mu \mathrm{g} / \mathrm{mL})$. Briefly, HepG2 cells were cultured in 96well microtiter plates in a final volume of $100 \mu \mathrm{L}$ culture medium per well. After incubation for 24 hours at $37^{\circ} \mathrm{C}$ and $5 \% \mathrm{CO}_{2}$, the GAS groups were pretreated with GAS $(5 \mu \mathrm{g} / \mathrm{mL}$, $25 \mu \mathrm{g} / \mathrm{mL}$, and $125 \mu \mathrm{g} / \mathrm{mL}$ ) for $12 \mathrm{~h}$. After that, the other four groups, except from the nature group, were treated with $\mathrm{H}_{2} \mathrm{O}_{2}$ $(1600 \mu \mathrm{M})$ for 4 hours. Then, the supernatant was licked off and washed once, $20 \mu \mathrm{L}$ of MTT $(5 \mathrm{mg} / \mathrm{mL})$ in PBS solution was added to each well, and the plate was further incubated for 4 hours. Most of the medium was removed and $100 \mu \mathrm{L}$ of DMSO was added into the wells to solubilize the crystals. Finally the optical density (OD) was measured by microplate reader at wave length of $490 \mathrm{~nm}$. All viability assays were performed in duplicate; its percentage growth inhibition was calculated using the following formula:

cell viability $(\%)$

$$
=\frac{\text { the absorbance of experimental group }}{\text { the natural group }} \times 100 \% \text {. }
$$

2.4. Hoechst 33258 Staining. Briefly, preparations of fixed cells were rinsed three times with PBS, permeabilised with $70 \%$ ethanol (30 s), and incubated with a solution of Hoechst $33258(2 \mu \mathrm{g} / \mathrm{mL})$ for $30 \mathrm{~min}$ at room temperature (RT). Then, the cells were observed by fluorescence microscope (Leica, Germany).

2.5. The Detection of ALT, AST, MDA, and SOD. ALT, AST, $\mathrm{MDA}$, and SOD in HepG2 cells were measured with commercial kits according to the manufacturer's recommendations. ALT, AST, and MDA levels and SOD activity were expressed as U/g.prot.

2.6. Flow Cytometry. Flow cytometry was performed as described before [15]. Briefly, the HepG2 cells were washed with cold PBS 2 times and then were resuspended in binding buffer (10 mM Hepes/ $\mathrm{NaOH}$ ( $\mathrm{pH} 7.4), 0.14 \mathrm{M} \mathrm{NaCl}$, and $2.5 \mathrm{mM} \mathrm{CaCl}_{2}$ ), and FITC Annexin V and PI were added. After incubation at room temperature for $15 \mathrm{~min}$ in the dark, flow cytometry was analyzed. Annexin V-FITC and PI double staining were regarded as late apoptotic or necrotic cells.

2.7. Caspase-3 and Caspase-9 Activity Elisa Kit Assays. Briefly, HepG2 cells were washed twice by PBS, digested with trypsin $(0.25 \%)$, and collected after centrifugation for 5 mins. Then, the HepG2 cells were lysed on ice (lysate $1 \mathrm{~mL}$ : PMSF $100 \mu \mathrm{L}: 11 \mu \mathrm{L}$ protease inhibitor), the protein was collected, and caspase- 3 and caspase- 9 were measured with commercial kits according to the manufacturer's recommendations.

2.8. Western Blotting Analysis. The expressions of Bcl-2 and Bax were detected by Western blotting. HepG2 cells were exposed to $1600 \mu \mathrm{M} \mathrm{H}_{2} \mathrm{O}_{2}$ with or without GAS. Cytoplasmic extracts were prepared with $150 \mu \mathrm{L}$ cell lysis buffer (lysis buffer:phenylmethylsulfonyl fluoride (PMSF):protease inhibitor cocktail $=100: 1: 1$ ) on ice for $30 \mathrm{~min}$, then the centrifuged supernatant was collected, and the protein concentration was quantified using the detergent-compatible (DC) protein assay kit (Bio-Rad, Richmond, CA, USA). Proteins were mixed with $2 \mathrm{x}$ sodium dodecyl sulphate (SDS) sample buffer. A total of $40 \mu \mathrm{g}$ of proteins were separated in a $10 \%(\mathrm{w} / \mathrm{v})$ polyacrylamide gel and blotted on a nitrocellulose membrane (Bio-Rad, Hercules, CA, USA). The blots were blocked for $2 \mathrm{~h}$ and incubated with polyantibodies Bcl-2, Bax, and tubulin at 1:2000 dilution for $12 \mathrm{~h}$. Subsequently, the membranes were washed in buffer (PBS with $0.1 \%(\mathrm{v} / \mathrm{v})$ Tween-20) and then incubated with horseradish peroxidase link-coupled rat anti-rabbit-antibody at 1:1000 in blocking buffer. In all experiments, Ponceau staining was carried out to control equal loading and the bands were visualized by electrogenerated chemiluminescence (ECL) Western blotting system (GE Healthcare Biosciences, USA). Protein levels were also analyzed by ImageJ software. The data shown are representative of at least three experiments.

2.9. Statistical Analysis. All data are expressed as mean \pm standard deviation (SD) and were analyzed using SPSS 13.0 software (SPSS, Chicago, IL). $p<0.05$ was considered statistically significant. 


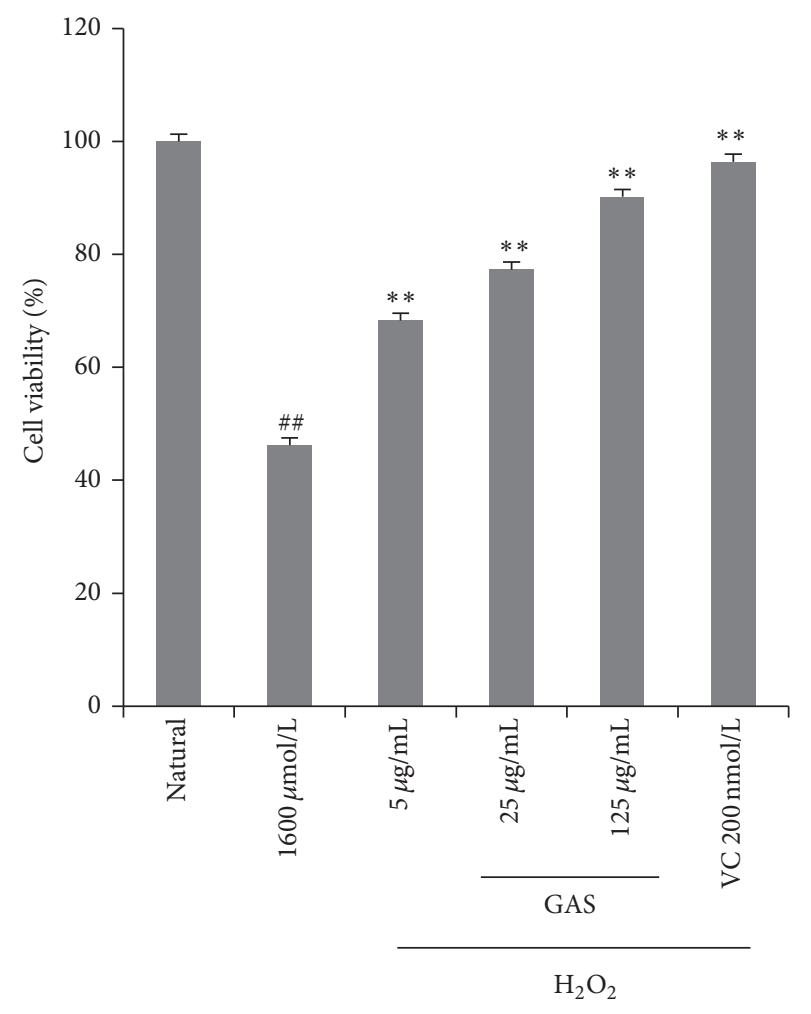

FIGURE 1: Cell viability of HepG2 cells following different concentrations of GAS pretreatment prior to $\mathrm{H}_{2} \mathrm{O}_{2}$ exposure $(1600 \mu \mathrm{M}, 4 \mathrm{~h})$ was measured by MTT assay. With increase of the concentration of $\mathrm{H}_{2} \mathrm{O}_{2}$, cell survival rate was gradually decreased, and with $\mathrm{H}_{2} \mathrm{O}_{2}(1600 \mu \mathrm{M})$ for 4 hours, its survival rate has been reduced to $52.20 \pm 1.13 \%$ compared to that of natural group. GAS groups $(5 \mu \mathrm{g} / \mathrm{mL}, 25 \mu \mathrm{g} / \mathrm{mL}$, and $125 \mu \mathrm{g} / \mathrm{mL})$ alleviated the cytotoxicity of HepG2 cells induced by $\mathrm{H}_{2} \mathrm{O}_{2}$, and increased cell viability. The annotation \#\# indicates a $p$ value $<0.05$ versus natural group; the annotation $* *$ indicates a $p$ value $<0.01$ versus $\mathrm{H}_{2} \mathrm{O}_{2}$ group.

\section{Result}

3.1. GAS Inhibits $\mathrm{H}_{2} \mathrm{O}_{2}$-Induced Cell Death of HepG2 Cells. To determine the proper working concentrations of $\mathrm{H}_{2} \mathrm{O}_{2}$, MTT assay was applied to detect the viability that HEPG2 cells were exposed to different concentrations of $\mathrm{H}_{2} \mathrm{O}_{2}$ with $4 \mathrm{~h}$ (data not shown). With the concentration of $\mathrm{H}_{2} \mathrm{O}_{2}$ increasing, cell survival rate was gradually decreased, and we found that $1600 \mu \mathrm{M} \mathrm{H}_{2} \mathrm{O}_{2}$ caused cell viability to decrease by about 50\%; its survival rate has been reduced to (52.20 \pm $1.13) \%$ compared to natural group. Therefore we exposed HepG2 cells to concentration of $1600 \mu \mathrm{M} \mathrm{H}_{2} \mathrm{O}_{2}$ for 4 hours to establish an oxidative stress injury model. However, GAS pretreatment groups $(5 \mu \mathrm{g} / \mathrm{mL}, 25 \mu \mathrm{g} / \mathrm{mL}$, and $125 \mu \mathrm{g} / \mathrm{mL})$ effectively protected HepG2 cells from $\mathrm{H}_{2} \mathrm{O}_{2}$-induced cell death $(n=6, p<0.01)$, and GAS alone has no effect on the cell viability of HepG2 cells (Figure 1). Moreover, the antioxidant Vitamin $\mathrm{C}$ pretreatment also can reverse the cell death induced by $\mathrm{H}_{2} \mathrm{O}_{2}$, and there is no significant difference between the GAS group $(125 \mu \mathrm{g} / \mathrm{mL})$ and Vitamin $\mathrm{C}$ group. The data indicates that GAS, similar to Vitamin C does, effectively protects HepG2 cells from $\mathrm{H}_{2} \mathrm{O}_{2}$-induced cell death.

3.2. GAS Inhibits $\mathrm{H}_{2} \mathrm{O}_{2}$-Induced HepG2 Cells Apoptosis. The Hoechst 33258 staining and Annexin V-FITC/PI doublestaining were applied to further evaluate the protective effect of GAS on $\mathrm{H}_{2} \mathrm{O}_{2}$-induced HepG2 cells apoptosis. The results of flow cytometry demonstrated that more apoptotic cells were countered in $\mathrm{H}_{2} \mathrm{O}_{2}$-treated group compared with natural group. The apoptotic percentage in the natural group was $5.30 \pm 1.20 \%$ (Figure 2(a)), which was significantly reduced than that in the $\mathrm{H}_{2} \mathrm{O}_{2}$ treated group $(42.66 \pm 1.54 \%)$ $(p<0.01)$ (Figure 2(b)). On the contrary, pretreatment of HepG2 cells with GAS $(25 \mu \mathrm{g} / \mathrm{mL}, 125 \mu \mathrm{g} / \mathrm{mL})$ prior to $\mathrm{H}_{2} \mathrm{O}_{2}$ showed the significant inhibition on cell apoptosis induced by $\mathrm{H}_{2} \mathrm{O}_{2}(p<0.01)$. The apoptotic percentage in the GAS groups is $19.52 \pm 1.19 \%$ (GAS $125 \mu \mathrm{g} / \mathrm{mL}$ ), $29.31 \pm 1.32 \%$ (GAS $25 \mu \mathrm{g} / \mathrm{mL}$ ), and $34.11 \pm 1.44 \%$ (GAS $5 \mu \mathrm{g} / \mathrm{mL}$ ), respectively, and the apoptotic percentage in the Vitamin $\mathrm{C}$ groups is $11.31 \pm 2.10 \%$.

After Hoechst 33258 staining, the HepG2 cells in the natural group showed normal shape with round intact nuclei (Figure 3(a)), whereas the $\mathrm{H}_{2} \mathrm{O}_{2}$-treated cells became more scarce and showed reduced nuclear size, extensive blebbing, strong fluorescent spot, and pyknotic nuclei (Figure 3(b)); these indicate condensed chromatin and apoptotic bodies. The GAS pretreatment groups $(25 \mu \mathrm{g} / \mathrm{mL}, 125 \mu \mathrm{g} / \mathrm{mL})$ show protective effect; it altered the morphologic changes in HepG2 induced by $\mathrm{H}_{2} \mathrm{O}_{2}$ (Figures 3(d), 3(e), and 3(f)).

\subsection{GAS Reduces the Increase of Lipid Peroxidation Induced} by $\mathrm{H}_{2} \mathrm{O}_{2}$ in HepG2 Cells. Since lipids in cell membrane were prone to oxidation, the effects of GAS in protecting against lipid peroxidation were also investigated. In the study, $\mathrm{H}_{2} \mathrm{O}_{2}$ was used as the source of ROS, which led to oxidative damage in HepG 2 cells, and the ALT, AST, MDA, and activity of SOD were measured in the study. The results showed that natural HepG2 cells had little basal intracellular ALT, AST, MDA, and high SOD activity. However, after $\mathrm{H}_{2} \mathrm{O}_{2}(1600 \mu \mathrm{M})$ exposure to 4 hours, cells had significantly increased intracellular ALT, AST, and MDA accumulation $(p<0.01)$ and significantly reduced intracellular SOD activity $(p<0.01)$. The results confirmed that $\mathrm{H}_{2} \mathrm{O}_{2}$ could induce ROS and led to cell damage in HepG2 cells. GAS pretreatment groups protected HepG2 cells damaged by $\mathrm{H}_{2} \mathrm{O}_{2}(1600 \mu \mathrm{M})$ (Figure 4) and attenuated the $\mathrm{H}_{2} \mathrm{O}_{2}$-induced changes in ALT, AST, MDA, and SOD activity. HepG2 cells treated with $\mathrm{H}_{2} \mathrm{O}_{2}$ alone evoked a significant increase in the MDA level (Figure 4(a)), approximately $50 \%$ higher than the natural group. HepG2 cells treated with GAS showed significant reduction $(p<$ 0.05) in MDA levels compared to $\mathrm{H}_{2} \mathrm{O}_{2}$ treated group (Figure $4(\mathrm{a}))$. In the GAS pretreatment groups $(5 \mu \mathrm{g} / \mathrm{mL}$, $25 \mu \mathrm{g} / \mathrm{mL}$, and $125 \mu \mathrm{g} / \mathrm{mL})$, SOD activity was dramatically increased compared with $\mathrm{H}_{2} \mathrm{O}_{2}$ treated group with a doseeffect relationship $(p<0.01$ ) (Figure 4(b)). Because of the inhibition of GAS on cell damage induced by $\mathrm{H}_{2} \mathrm{O}_{2}$, we detected less AST and ALT in GAS treated group compared to that of $\mathrm{H}_{2} \mathrm{O}_{2}$ treated group $(p<0.01)$ (Figures $4(\mathrm{c})$ and $4(d))$. 


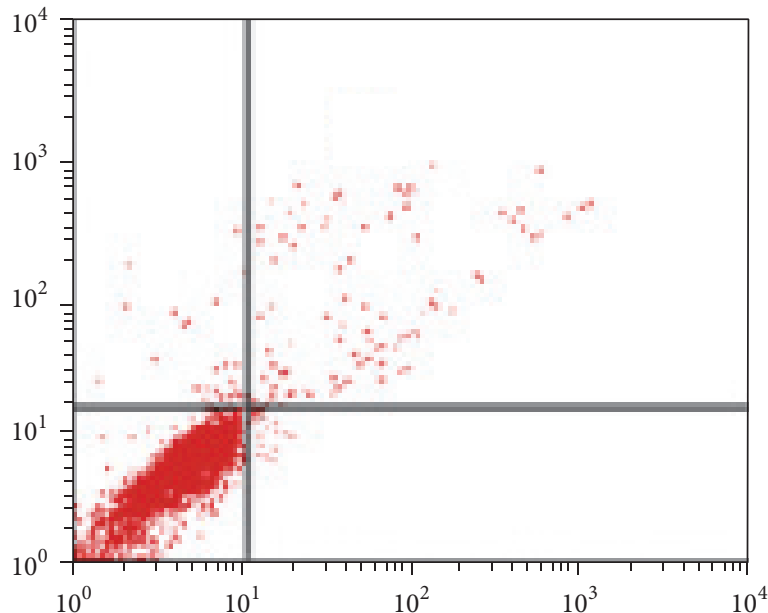

(a)

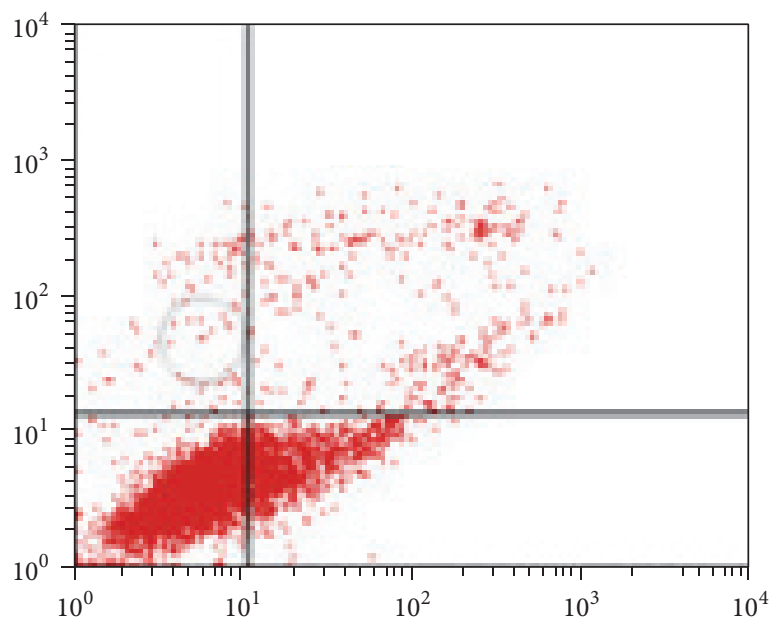

(c)

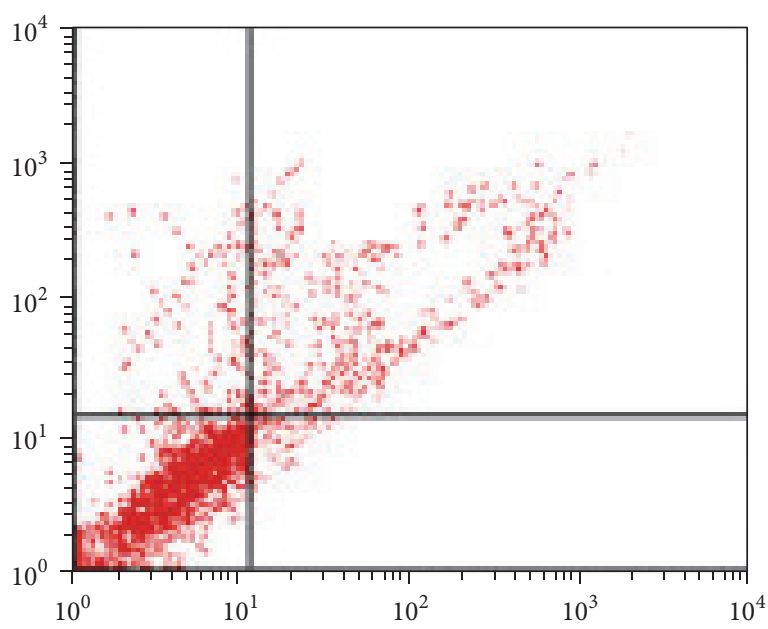

(e)

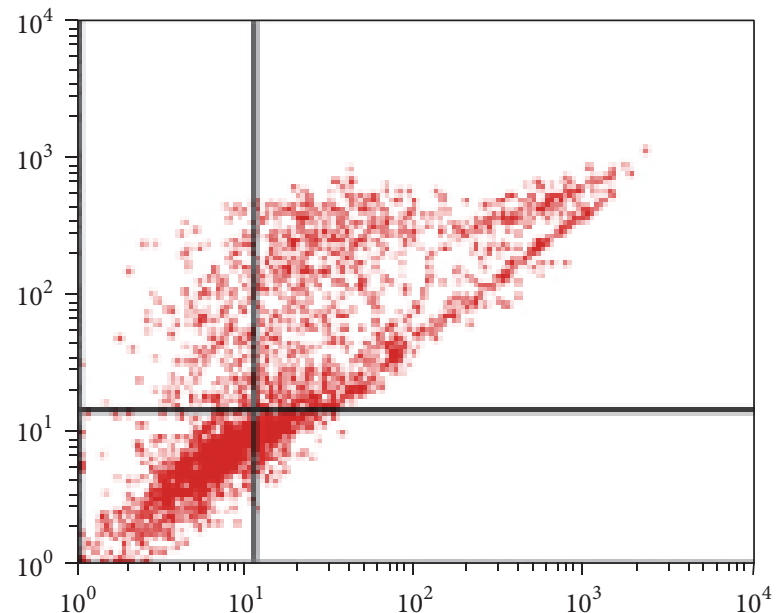

(b)

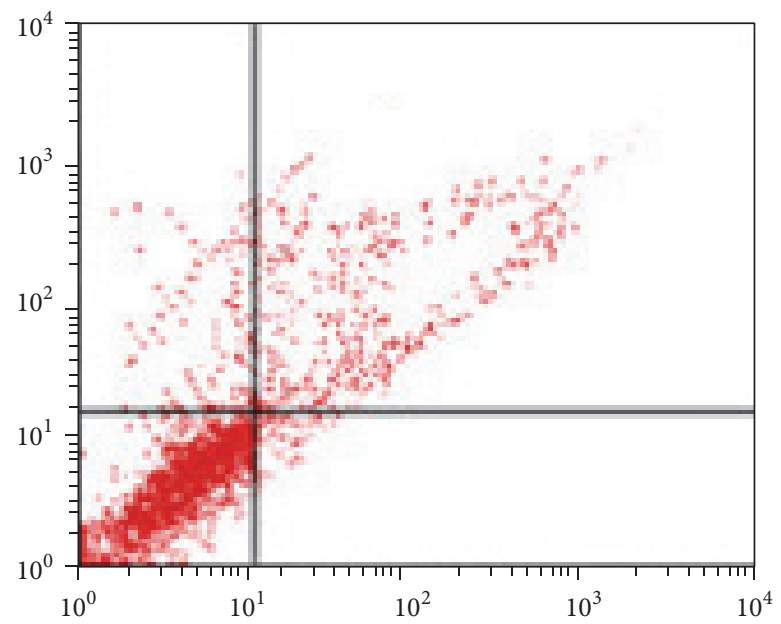

(d)

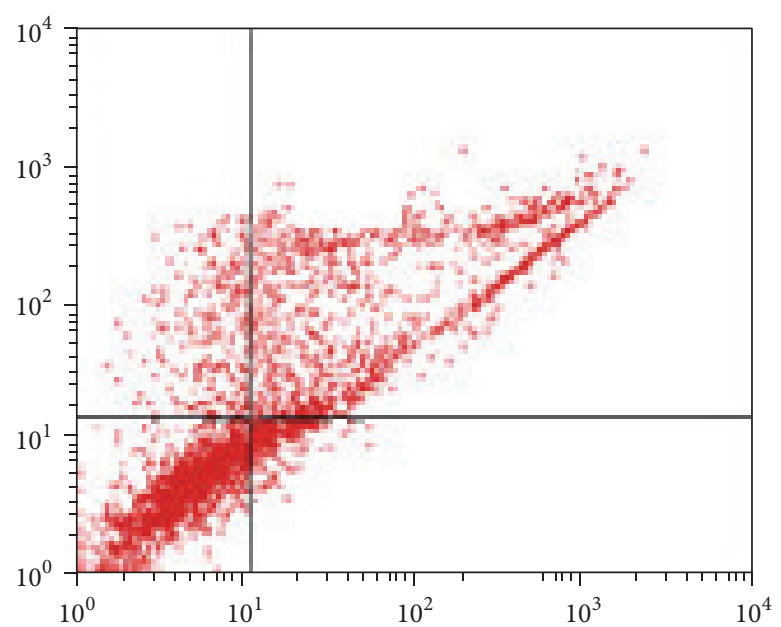

(f)

FIGURE 2: Cells were stained with Annexin V-FITC/PI for verifying the apoptotic or necrotic cell ratio. GAS inhibited $\mathrm{H}_{2} \mathrm{O}_{2}$-induced $\mathrm{HEPG} 2$ cells apoptosis. (a) Natural group; (b) $\mathrm{H}_{2} \mathrm{O}_{2}$ group; (c) $\mathrm{H}_{2} \mathrm{O}_{2}+$ Vitamin $\mathrm{C}(200 \mathrm{nM})$ group; (d) $\mathrm{H}_{2} \mathrm{O}_{2}+\mathrm{GAS}(125 \mu \mathrm{g} / \mathrm{mL})$ group; (e) $\mathrm{H}_{2} \mathrm{O}_{2}+$ GAS $(25 \mu \mathrm{g} / \mathrm{mL})$ group; (f) $\mathrm{H}_{2} \mathrm{O}_{2}+\mathrm{GAS}(5 \mu \mathrm{g} / \mathrm{mL}$ group). 

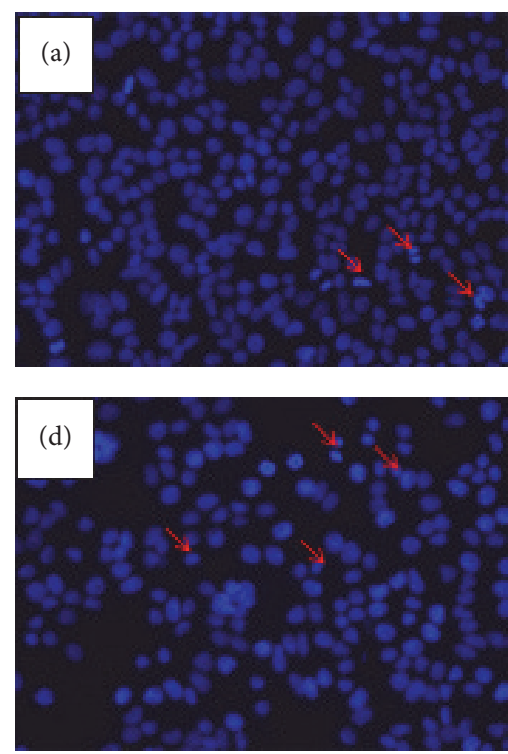
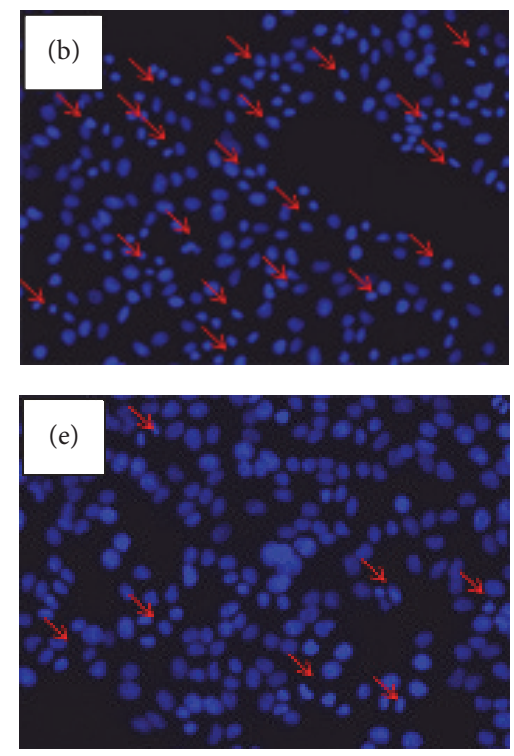
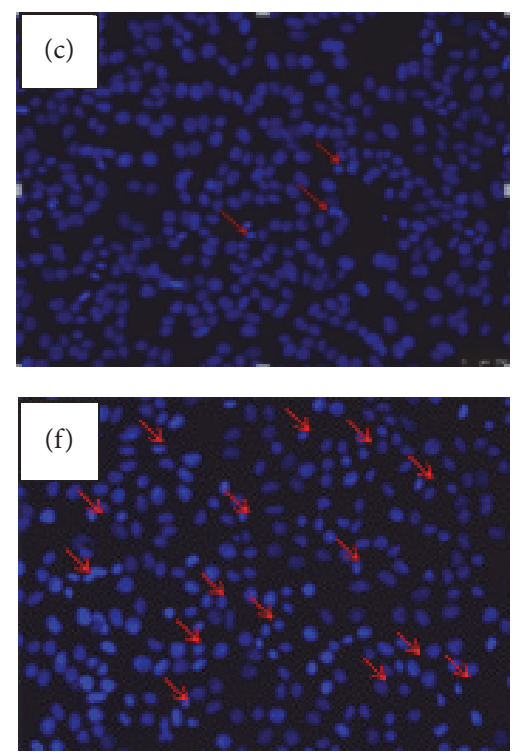

FIGURE 3: Hoechst 33258 staining indicated that GAS inhibits $\mathrm{H}_{2} \mathrm{O}_{2}$-induced HepG2 cells apoptosis. Morphologic changes in nuclei observed with Hoechst 33258 staining under fluorescence microscopy. (a) Natural group. The HepG2 cells showed normal shape with round intact nuclei; (b) $\mathrm{H}_{2} \mathrm{O}_{2}$ group, HepG2 cells treated with $1600 \mu \mathrm{M} \mathrm{H}_{2} \mathrm{O}_{2}$ for 4 hours, and the obvious morphologic changes were observed; (c) $\mathrm{H}_{2} \mathrm{O}_{2}$ + Vitamin C (200 nM) group; (d) $\mathrm{H}_{2} \mathrm{O}_{2}+\mathrm{GAS}(125 \mu \mathrm{g} / \mathrm{mL})$ group; (e) $\mathrm{H}_{2} \mathrm{O}_{2}+\mathrm{GAS}\left(25 \mu \mathrm{g} / \mathrm{mL}\right.$ ) group; (f) $\mathrm{H}_{2} \mathrm{O}_{2}+\mathrm{GAS}(5 \mu \mathrm{g} / \mathrm{mL})$ group. The arrows indicate apoptotic cells. Original magnification is $400 \mathrm{x}$.

3.4. GAS Inhibits Activation of Caspase and Expression of Bcl-2 and Bax Induced by $\mathrm{H}_{2} \mathrm{O}_{2}$ in HepG2 Cells. As an important modulator of cell death, caspase cascade activation was evaluated in our study. We measured the activities of caspase- 9 and caspase- 3 by ELISA Kit. As shown in Figures 5(a) and 5(b), caspase- 9 and caspase-3 were activated by $\mathrm{H}_{2} \mathrm{O}_{2}$-induced, and GAS effectively inhibited caspase- 9 and caspase- 3 activation in a dose-dependent manner. These results demonstrated that GAS prevented $\mathrm{H}_{2} \mathrm{O}_{2}$-induced apoptosis through inhibition of mitochondrial-dependent cell death pathways.

The potential role of ROS in Bax and Bcl-2 activation has been indicated in multiple cell death signaling $[16,17]$. Bax activation in inducing the cell death by ROS is the critical initiators. Bcl-2 family proteins acts as the gate keepers of cell death at mitochondria, which plays a critical role in regulating Bax induced mitochondrial permeability. As shown in Figures 5(c) and 5(d), Bcl-2 was downexpressed, and the expression of Bax was upregulated after the $\mathrm{H}_{2} \mathrm{O}_{2}$ treated in HepG2 cells. GAS pretreatment group upregulated the expression of $\mathrm{Bcl}-2$ and suppressed the Bax expression with a dose-effect relationship. These results demonstrated that GAS inhibited $\mathrm{H}_{2} \mathrm{O}_{2}$-induced apoptosis through inhibition of Bcl2 dependent cell death pathways.

\section{Discussion}

In our study, HepG2 cells were used as a cellular model to investigate the effects of GAS on the antioxidant defense systems. We had shown that $\mathrm{H}_{2} \mathrm{O}_{2}$ markedly decreased the viability of HEPG2 cells, whereas pretreatment with GAS significantly inhibited cell injury, as demonstrated by MTT assay. We also detected content of AST, ALT, and MDA, with and without $\mathrm{H}_{2} \mathrm{O}_{2}$; our results indicated that $\mathrm{H}_{2} \mathrm{O}_{2}$ could induce HEPG2 cells damage, which led to the increase of AST, ALT, and MDA and reduction of SOD activity. Oxidative stress caused by ROS is responsible for a wide variety of cellular damage and is the most validated mechanism of secondary injury [18]. Following oxidative stress, the overproduction of ROS and subsequently the depletion of antioxidants resulted in the total breakdown of the endogenous antioxidant defense mechanisms, culminating in failure to protect cells from oxidative damage. Among biomarkers of oxidative stress, MDA and SOD are known as two sensitive indicators [19]. MDA is the end product of lipid peroxidation [20] and MDA levels reflect the extent of cell damage due to oxidative stress. $\mathrm{H}_{2} \mathrm{O}_{2}$ may induce the generation of ROS at mitochondria which has been widely used as a model exogenous oxidative stress mediated experiment in hepatocellular apoptosis [21]. GAS pretreatment effectively protected HEPG2 cells from $\mathrm{H}_{2} \mathrm{O}_{2}$-induced damage. GAS increased the activity of SOD, decreased the level of ALT, AST, and MDA, and inhibited the apoptosis induced by $\mathrm{H}_{2} \mathrm{O}_{2}$.

Apoptosis may be activated by the intrinsic or by the extrinsic pathway [22]. Caspases are a group of aspartate specific cysteine protease, which plays a key role in regulating the apoptosis induced by different kind of stimuli including oxidative stress [23]. Functionally, caspase-3 is an important effector in the apoptotic process, and caspase- 9 is an initiator of caspase-3 in the mitochondria-dependent pathway [24]. Treatment of $\mathrm{H}_{2} \mathrm{O}_{2}$ to the HEPG2 cells increased the caspase- 9 expression in cells, which indicated that the mitochondrial pathway plays an important function in $\mathrm{H}_{2} \mathrm{O}_{2}$ induced apoptosis in cells. In our study, $\mathrm{H}_{2} \mathrm{O}_{2}$ upregulated the expression of caspase- 3 and caspase- 9 in HepG 2 cells treated with $\mathrm{H}_{2} \mathrm{O}_{2}$; it indicated that the apoptosis induced by $\mathrm{H}_{2} \mathrm{O}_{2}$ 


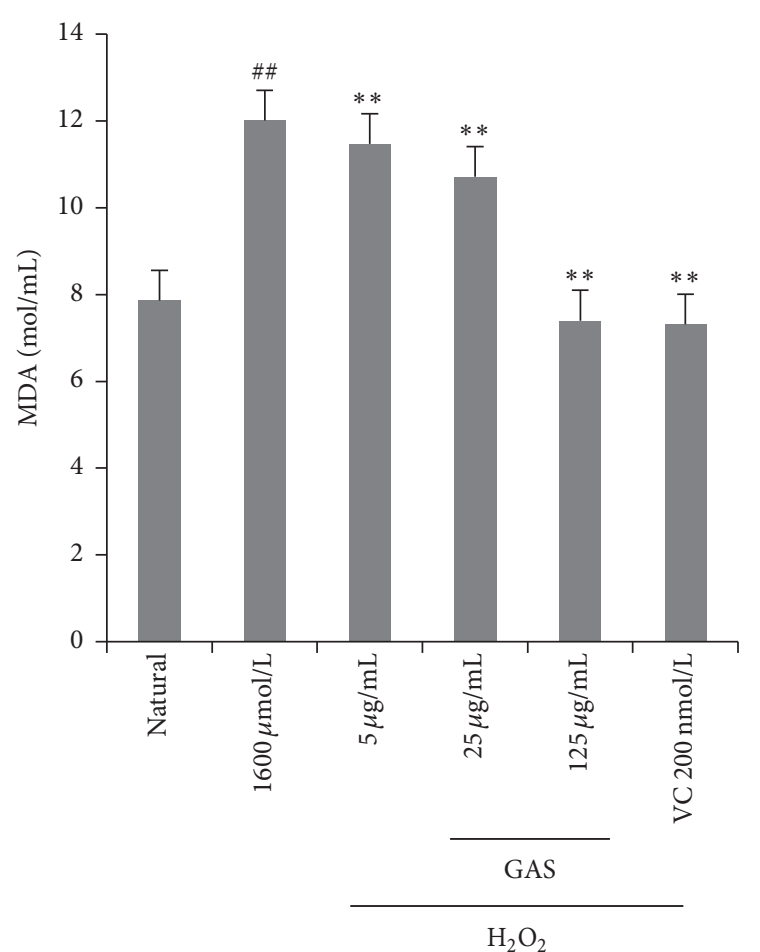

(a)

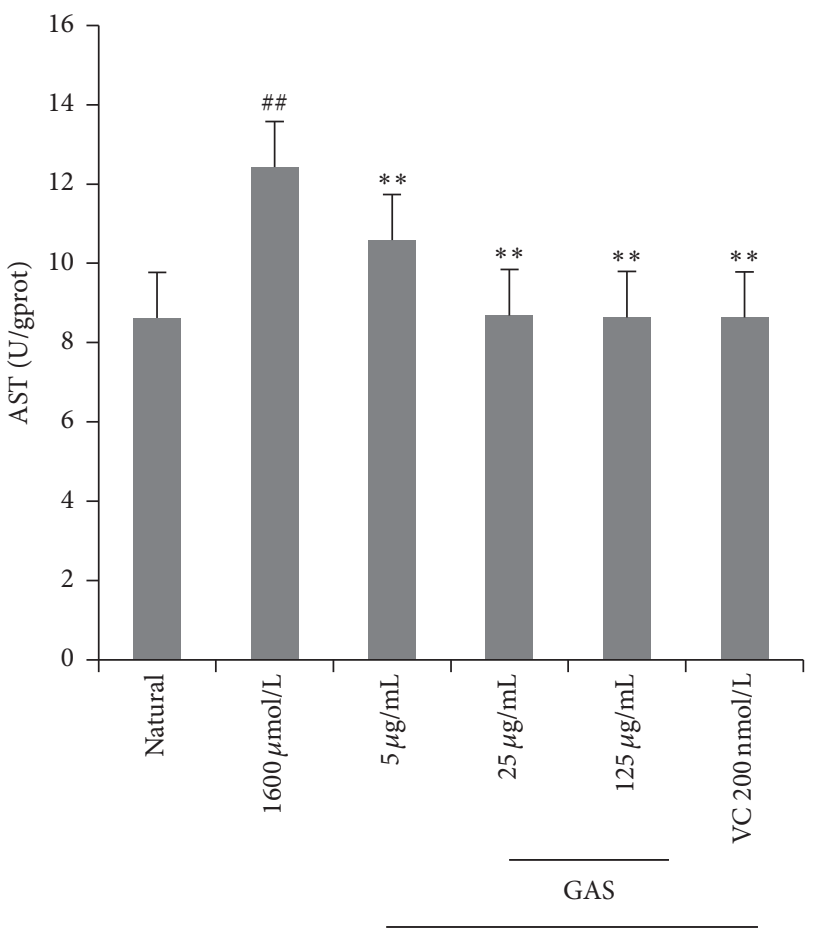

$\mathrm{H}_{2} \mathrm{O}_{2}$

(c)

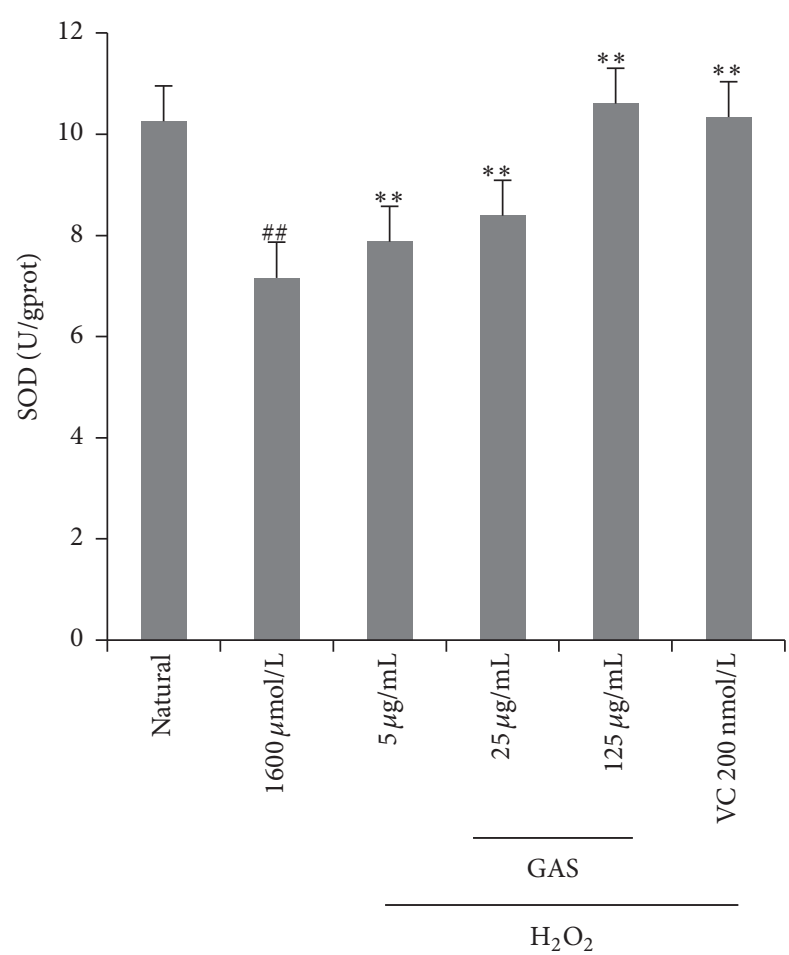

(b)

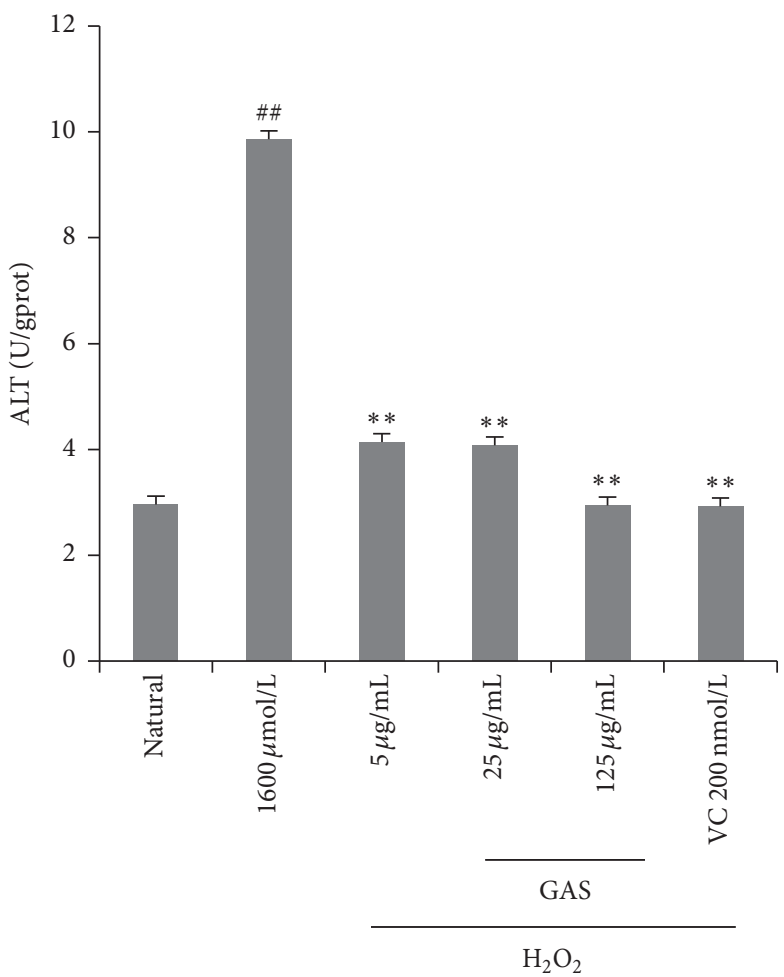

(d)

FIGURE 4: Biochemical assay kits were used to determine content of ALT, AST, MDA, and SOD. GAS protected the cells against $\mathrm{H}_{2} \mathrm{O}_{2}$-induced lipid peroxidation in $\mathrm{HepG} 2$ cells and reduced $\mathrm{H}_{2} \mathrm{O}_{2}$-induced reactive protein production. ALT, AST, and MDA content and SOD activity were measured in HepG2 cells. (a) The MDA level in HepG2 cells; (b) the SOD activity in HepG2 cells; (c) the content of AST; (d) the content of ALT. Error bars represent SD $(n=6)$. Experiments were performed at least three times. The annotation \#\# indicates a $p$ value $<0.01$ versus natural group. The annotation $* *$ indicates a $p$ value $<0.01$ versus $\mathrm{H}_{2} \mathrm{O}_{2}$ group. 


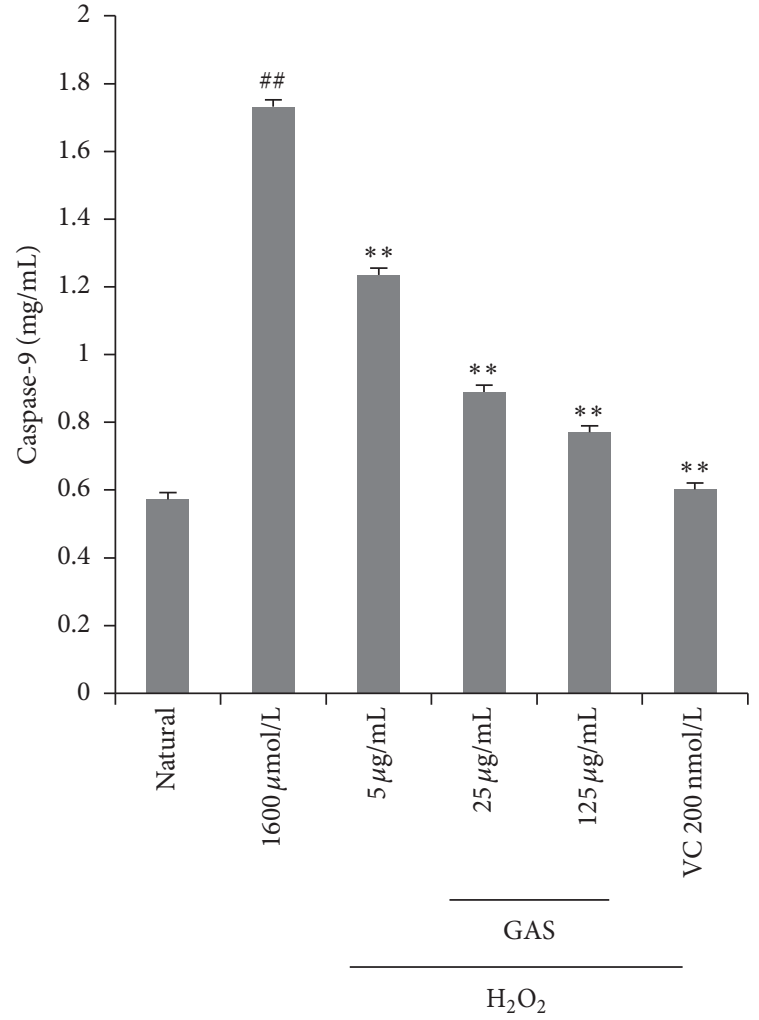

(a)

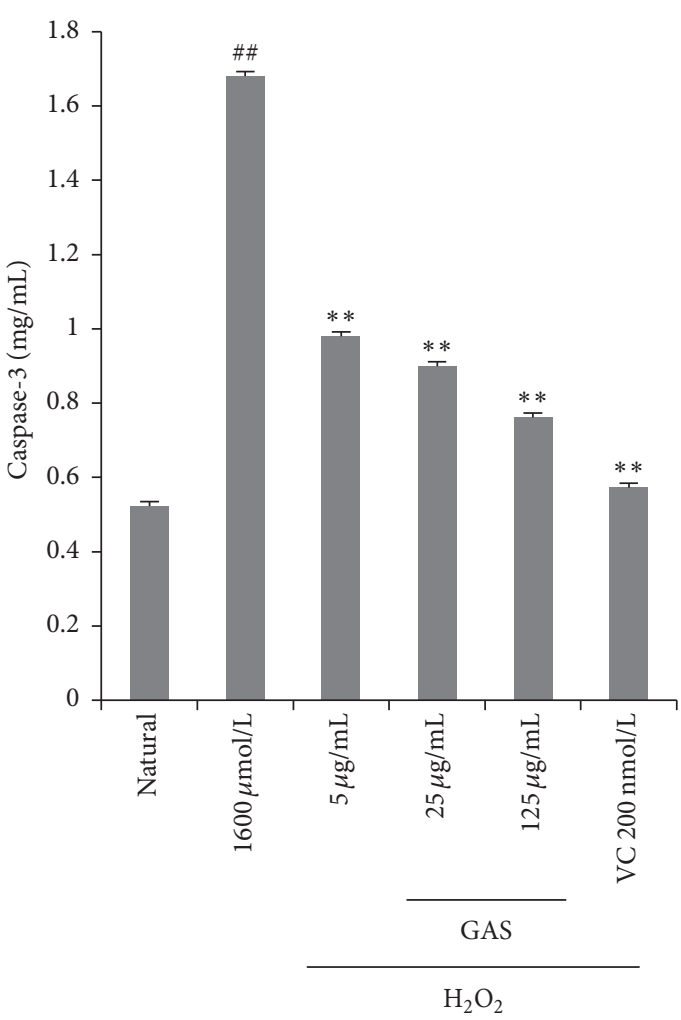

(b)
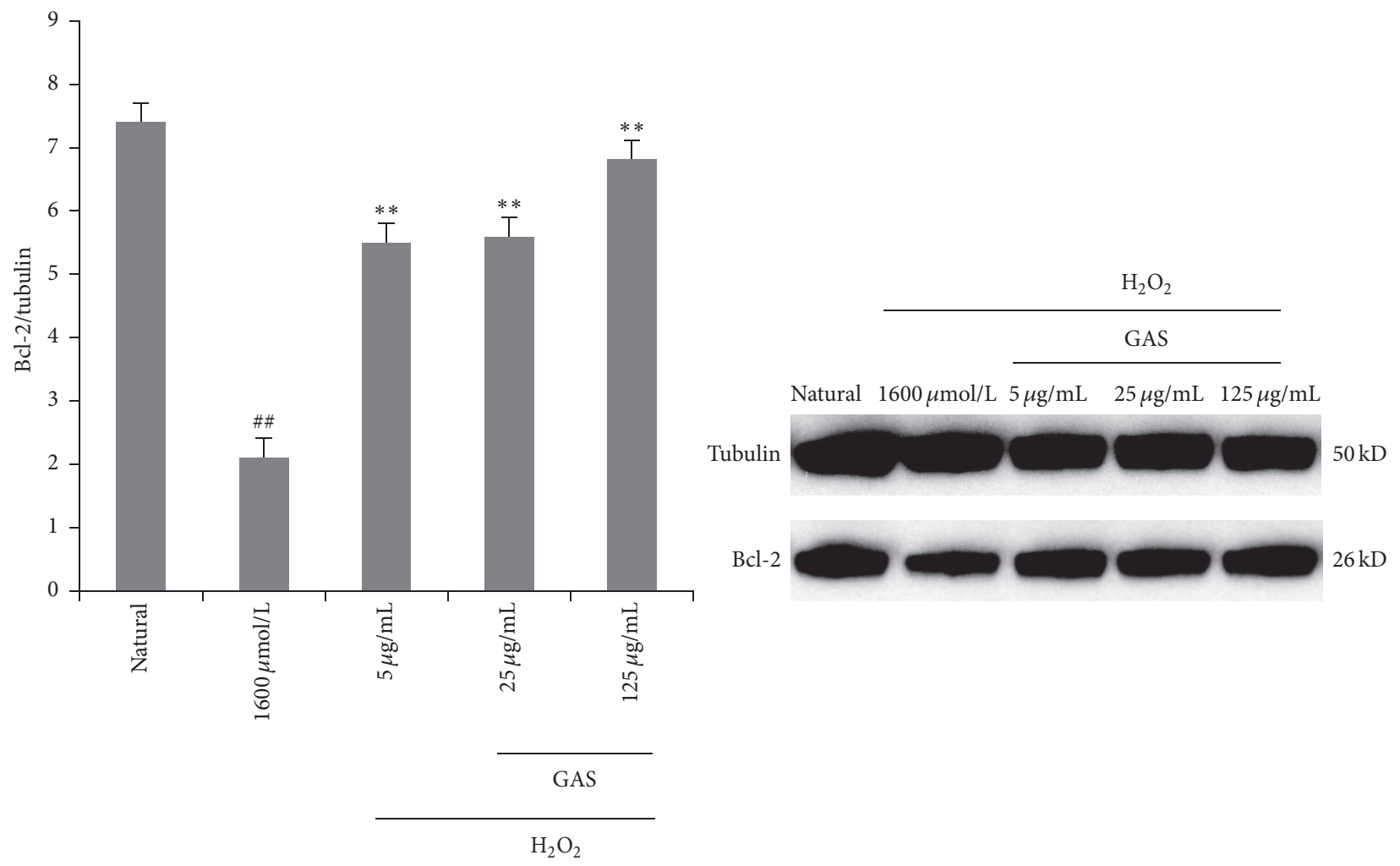

(c)

FIgure 5: Continued. 


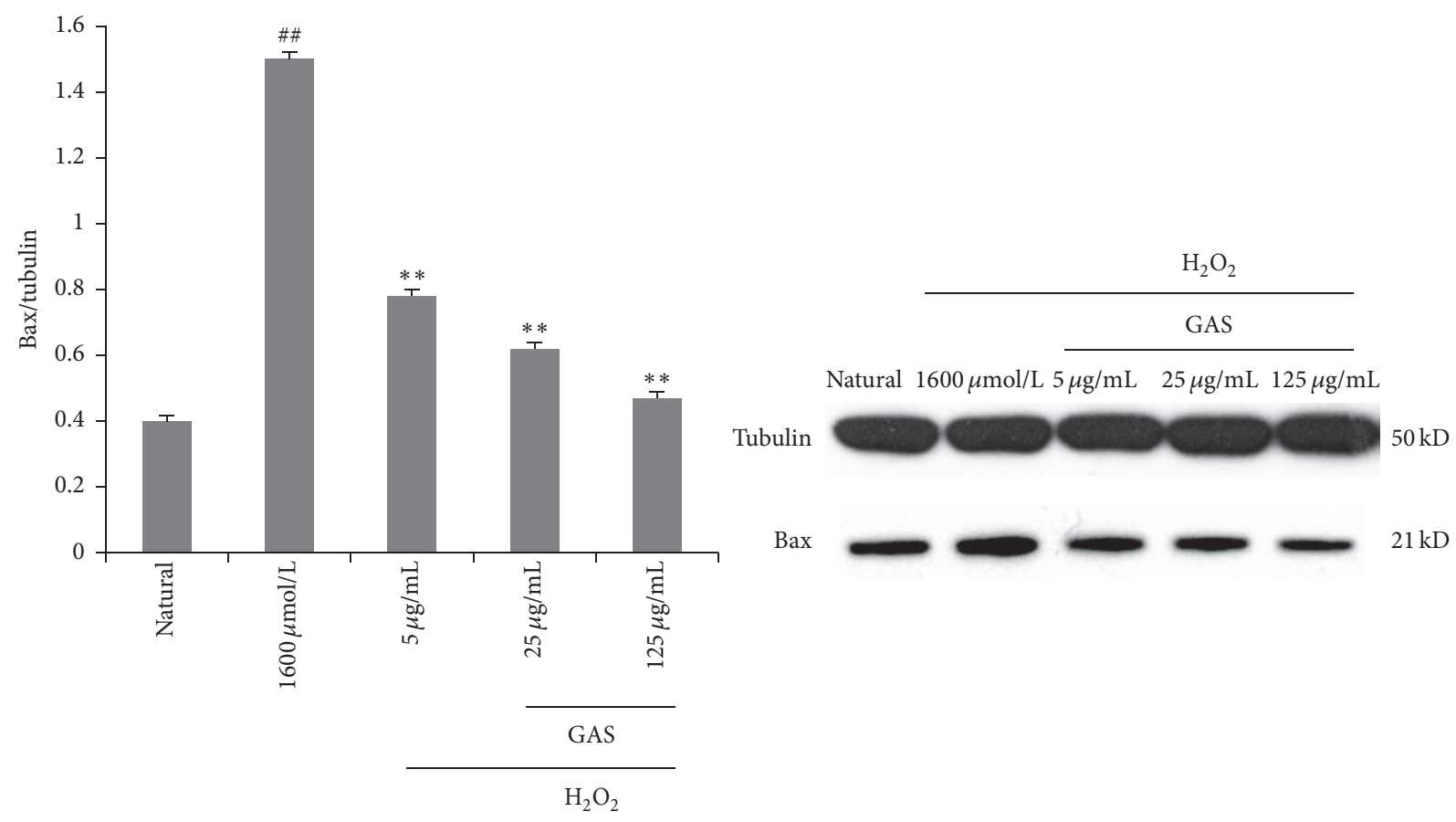

(d)

Figure 5: GAS inhibit the apoptosis induced by $\mathrm{H}_{2} \mathrm{O}_{2}$ in HepG2 cells: (a) the activity of caspase-9; (b) the activity of caspase-3; (c) the expression of $\mathrm{Bcl}-2$; (d) the expression of Bax. The annotation \#\# indicates a $p$ value $<0.01$ versus natural group. The annotation $* *$ indicates a $p$ value $<0.01$ versus $\mathrm{H}_{2} \mathrm{O}_{2}$ group.

through activation of caspases cascade. Bcl-2 proteins are major regulators of mitochondrial cytochrome $\mathrm{c}$ and caspases activation. It plays an important role in the regulation of cell apoptosis [25]. This family contains both proapoptotic and antiapoptotic proteins (Bcl-2 and Bcl-XL). Bcl-2 is an important cellular component which can protect against apoptotic cell death. Bax proteins were confirmed that could promote apoptosis. Our study proved that GAS reversed Bax upexpression and Bcl-2 downexpression and suppressed the activity of caspase- 9 and caspase- 3 in HepG2 cells after exposure to $\mathrm{H}_{2} \mathrm{O}_{2}$. It could be concluded that cell death evoked by $\mathrm{H}_{2} \mathrm{O}_{2}$ is regulated by $\mathrm{Bcl}-2$ family proteins; $\mathrm{Bcl}-$ 2 downexpression leads to the release of cytochrome $\mathrm{c}$ from the damaged mitochondria, which then binds to the adaptor molecule APAF-1 and an inactive "initiator" caspase, procaspase- 9 , within a multiprotein complex called the apoptosome. This leads to the activation of caspase-9, which then triggers a cascade of caspases activation (caspase- 3 and caspase-7) resulting in the morphological and biochemical changes associated with apoptosis. The Bcl-2 upexpression of GAS may be the key mechanism for antiapoptosis induced by ROS in HepG2 cells.

In summary, the present study shows that $\mathrm{H}_{2} \mathrm{O}_{2}$ can induce HepG2 cells injury and induce cells apoptosis. GAS protects human $\mathrm{HepG} 2$ cells against $\mathrm{H}_{2} \mathrm{O}_{2}$-induced oxidative stress, cells apoptosis, ROS activity, and activities of caspase-9 and caspase-3. GAS also can regulate the expression of $\mathrm{Bcl} 2$ and Bax. GAS-mediated protection can be conferred by one or more of the following mechanisms: GAS could reduce the oxidative stress injury. Second, GAS could attenuate apoptosis through inhibiting the subsequent biochemical changes in the Bcl-2 apoptotic pathway. These data help explain the protective action of GAS against cell injuries involving the mitochondrial pathway.

\section{Disclosure}

The authors are responsible for the content and writing of this article.

\section{Competing Interests}

The authors report no conflict of interests.

\section{Acknowledgments}

This work was funded by National Natural Science Foundation of China (nos. 81260650, 81560685, and 81260615), Natural Science Foundation of Inner Mongolian (no. KJT14BS 805), Youth Science and Technology Fellowship Program of Inner Mongolia Educational Department (no. JYT14GNYC 03), and Inner Mongolia Department of Education Science Projects (no. JYT14133).

\section{References}

[1] K. W. Kong, S. Mat-Junit, N. Aminudin et al., "Protective effects of the extracts of barringtonia racemosa shoots against oxidative damage in hepg2 cells," PeerJ, vol. 4, Article ID e1628, 2016. 
[2] Y. Zhang, D. Yuan, W. Yao et al., "Hyperglycemia aggravates hepatic ischemia reperfusion injury by inducing chronic oxidative stress and inflammation," Oxidative Medicine and Cellular Longevity, vol. 2016, Article ID 3919627, 16 pages, 2016.

[3] R. Voltan, P. Secchiero, F. Casciano, D. Milani, G. Zauli, and V. Tisato, "Redox signaling and oxidative stress: cross talk with TNF-related apoptosis inducing ligand activity," The International Journal of Biochemistry \& Cell Biology, 2016.

[4] D. Martín, M. Salinas, N. Fujita, T. Tsuruo, and A. Cuadrado, "Ceramide and reactive oxygen species generated by $\mathrm{H}_{2} \mathrm{O}_{2}$ induce caspase-3-independent degradation of Akt/protein kinase B," Journal of Biological Chemistry, vol. 277, no. 45, pp. 42943-42952, 2002.

[5] A. Dumont, S. P. Hehner, T. G. Hofmann, M. Ueffing, W. Dröge, and M. L. Schmitz, "Hydrogen peroxide-induced apoptosis is CD95-independent, requires the release of mitochondriaderived reactive oxygen species and the activation of NF- $\kappa \mathrm{B}$," Oncogene, vol. 18, no. 3, pp. 747-757, 1999.

[6] H. Jaeschke, "Reactive oxygen and mechanisms of inflammatory liver injury," Journal of Gastroenterology and Hepatology, vol. 15, no. 7, pp. 718-724, 2000.

[7] D. L. Tribble, T. Y. Aw, and D. P. Jones, “The pathophysiological significance of lipid peroxidation in oxidative cell injury," Hepatology, vol. 7, no. 2, pp. 377-386, 1987.

[8] K. K. Cole and J. R. Perez-Polo, "Poly(ADP-ribose) polymerase inhibition prevents both apoptotic-like delayed neuronal death and necrosis after $\mathrm{H}_{2} \mathrm{O}_{2}$ injury," Journal of Neurochemistry, vol. 82, no. 1, pp. 19-29, 2002.

[9] R. P. Englert and E. Shacter, "Distinct modes of cell death induced by different reactive oxygen species: amino acyl chloramines mediate hypochlorous acid-induced apoptosis," The Journal of Biological Chemistry, vol. 277, no. 23, pp. 20518-20526, 2002.

[10] G. Szabo, J. R. Wands, A. Eken et al., "Alcohol and hepatitis C virus-interactions in immune dysfunctions and liver damage," Alcoholism: Clinical and Experimental Research, vol. 34, no. 10, pp. 1675-1686, 2010.

[11] X. Zhang and J. J. Lemastersn, "Translocation of iron from lysosomes to mitochondria during ischemia predisposes to injury after reperfusion in rat hepatocytes," Free Radical Biology and Medicine, vol. 63, pp. 243-253, 2013.

[12] R. H. Bhogal, C. J. Weston, S. M. Curbishley, D. H. Adams, and S. C. Afford, "Autophagy: a cyto-protective mechanism which prevents primary human hepatocyte apoptosis during oxidative stress," Autophagy, vol. 8, no. 4, pp. 545-558, 2012.

[13] M. M. Hafez, O. A. Al-Shabanah, N. O. Al-Harbi et al., "Association between paraoxonases gene expression and oxidative stress in hepatotoxicity induced by $\mathrm{CCl}_{4}$," Oxidative Medicine and Cellular Longevity, vol. 2014, Article ID 893212, 12 pages, 2014.

[14] K. Ikeda, "Glycyrrhizin injection therapy prevents hepatocellular carcinogenesis in patients with interferon-resistant active chronic hepatitis C," Hepatology Research, vol. 37, no. 2, pp. S287-S293, 2007.

[15] J.-J. Park, K.-H. Lim, and K.-H. Baek, "Annexin-1 regulated by HAUSP is essential for UV-induced damage response," Cell Death \& Disease, vol. 6, no. 2, Article ID e1654, 2015.

[16] S. Zhang, Q. Liu, Y. Liu, H. Qiao, and Y. Liu, "Zerumbone, a Southeast Asian ginger sesquiterpene, induced apoptosis of pancreatic carcinoma cells through p53 signaling pathway," Evidence-Based Complementary and Alternative Medicine, vol. 2012, Article ID 936030, 8 pages, 2012.
[17] S. Yodkeeree, B. Sung, P. Limtrakul, and B. B. Aggarwal, "Zerumbone enhances TRAIL-induced apoptosis through the induction of death receptors in human colon cancer cells: evidence for an essential role of reactive oxygen species," Cancer Research, vol. 69, no. 16, pp. 6581-6589, 2009.

[18] J.-J. Xu and Y.-L. Wang, "Propofol attenuation of hydrogen peroxide-mediated oxidative stress and apoptosis in cultured cardiomyocytes involves haeme oxygenase-1," European Journal of Anaesthesiology, vol. 25, no. 5, pp. 395-402, 2008.

[19] S. Zhu, I. G. Stavrovskaya, M. Drozda et al., "Minocycline inhibits cytochrome $c$ release and delays progression of amyotrophic lateral sclerosis in mice," Nature, vol. 417, no. 6884, pp. 74-78, 2002.

[20] A. N. Torun, S. Kulaksizoglu, M. Kulaksizoglu, B. O. Pamuk, E. Isbilen, and N. B. Tutuncu, "Serum total antioxidant status and lipid peroxidation marker malondialdehyde levels in overt and subclinical hypothyroidism," Clinical Endocrinology, vol. 70, no. 3, pp. 469-474, 2009.

[21] D. B. Zorov, C. R. Filburn, L. O. Klotz et al., "Reactive oxygen species (ROS)-induced ROS release: a new phenomenon accompanying induction of the mitochondrial permeability transition in cardiac myocytes," Journal of Experimental Medicine, vol. 192, no. 7, pp. 1001-1014, 2000.

[22] S. W. Ryter, P. K. Hong, A. Hoetzel et al., "Mechanisms of cell death in oxidative stress," Antioxidants and Redox Signaling, vol. 9, no. 1, pp. 49-89, 2007.

[23] W. C. Earnshaw, L. M. Martins, and S. H. Kaufmann, "Mammalian caspases: structure, activation, substrates, and functions during apoptosis," Annual Review of Biochemistry, vol. 68, pp. 383-424, 1999.

[24] B. Jiang, W. Xiao, Y. Shi, M. Liu, and X. Xiao, "Heat shock pretreatment inhibited the release of Smac/DIABLO from mitochondria and apoptosis induced by hydrogen peroxide in cardiomyocytes and $\mathrm{C}_{2} \mathrm{C}_{12}$ myogenic cells," Cell Stress and Chaperones, vol. 10, no. 3, pp. 252-262, 2005.

[25] R. Sugioka, S. Shimizu, T. Funatsu et al., "BH4-domain peptide from $\mathrm{Bcl}-\mathrm{x}_{\mathrm{L}}$ exerts anti-apoptotic activity in vivo," Oncogene, vol. 22, no. 52, pp. 8432-8440, 2003. 


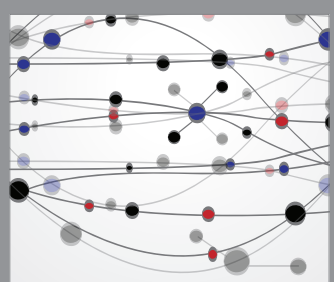

The Scientific World Journal
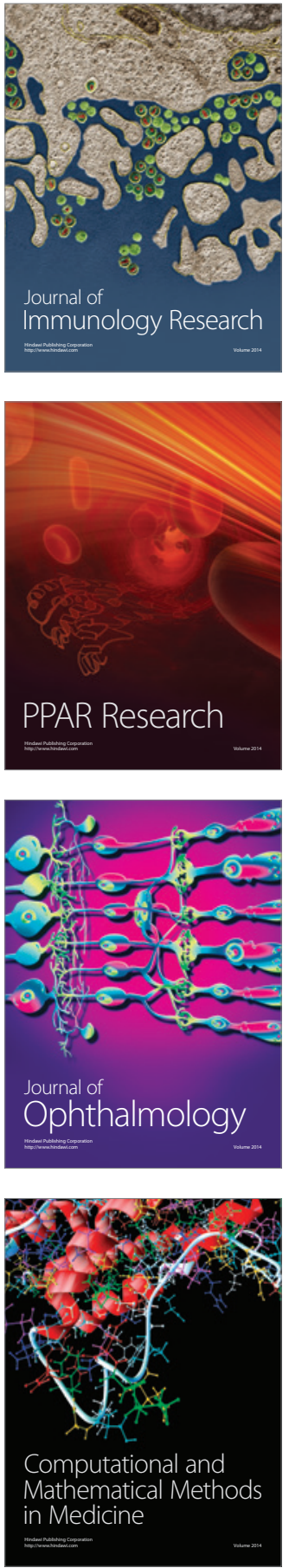

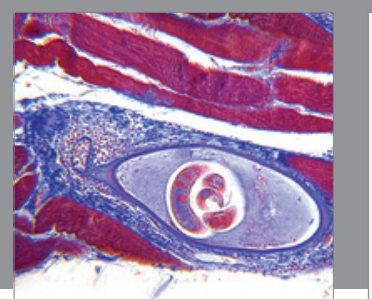

Gastroenterology Research and Practice

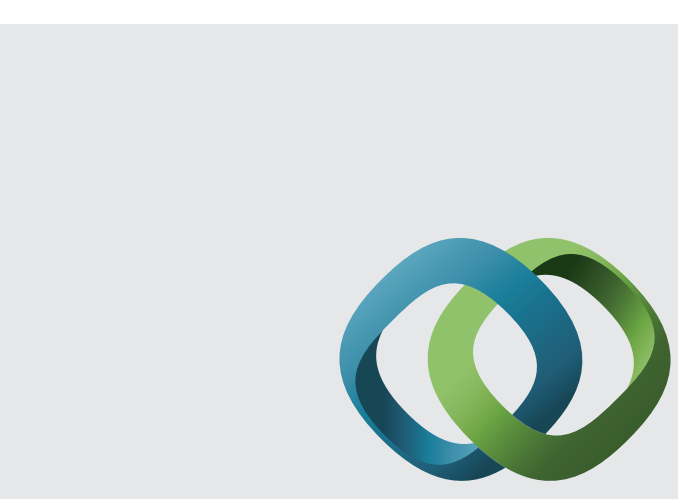

\section{Hindawi}

Submit your manuscripts at

http://www.hindawi.com
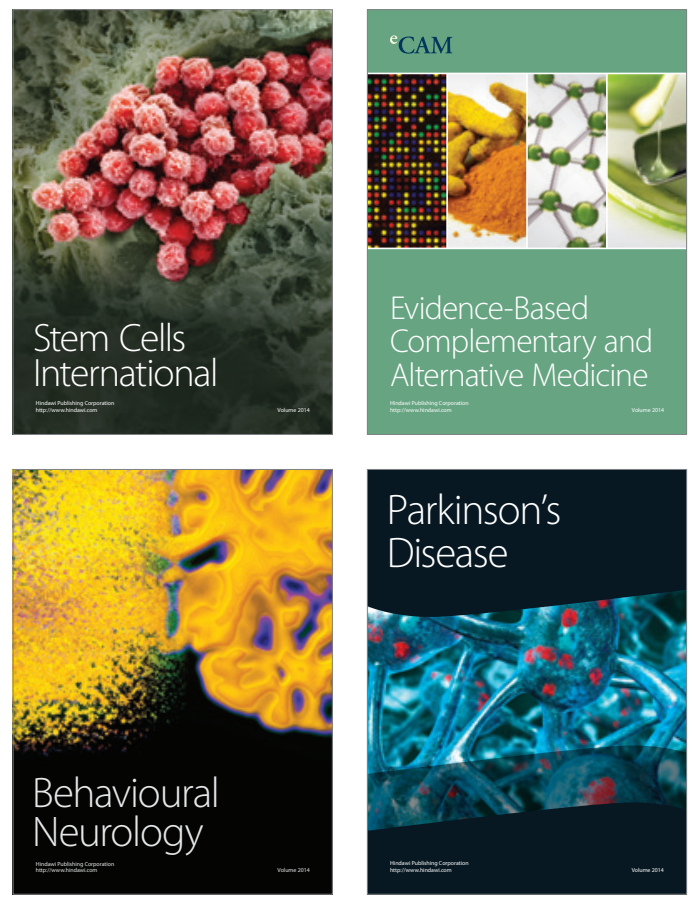
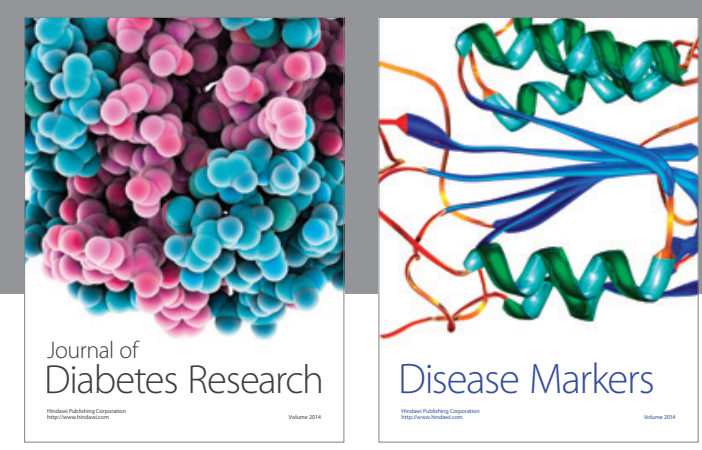

Disease Markers
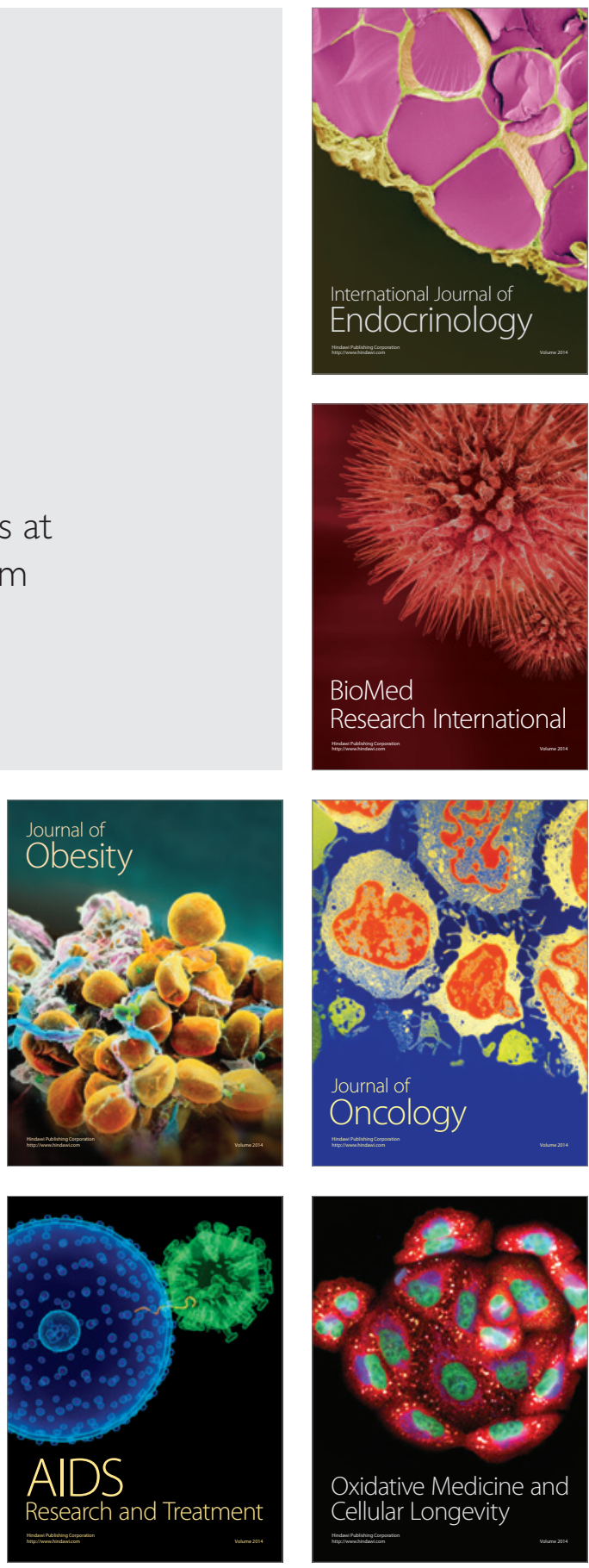